\title{
In vitro pituitary and testicular effects of the leptin-related synthetic peptide leptin(116-130) amide involve actions both similar to and distinct from those of the native leptin molecule in the adult rat
}

\author{
Manuel Tena-Sempere ${ }^{1}$, Leonor Pinilla ${ }^{1}$, Lucas C González ${ }^{1}$, Juan Navarro ${ }^{1}$, Carlos Diéguez ${ }^{2}$, \\ Felipe F Casanueva ${ }^{3}$ and Enrique Aguilar ${ }^{1}$ \\ ${ }^{1}$ Department of Physiology, Faculty of Medicine, University of Córdoba, Avda Menéndez Pidal s/n, 14004 Córdoba, Spain and \\ Departments of ${ }^{2}$ Physiology and ${ }^{3}$ Medicine, University of Santiago de Compostela, Santiago de Compostela, Spain \\ (Correspondence should be addressed to M Tena-Sempere,E-mail: fi1tesem@lucano.uco.es)
}

\begin{abstract}
The obese gene $(o b)$ product, leptin, has recently emerged as a key element in body weight homeostasis, neuroendocrine function and fertility. Identification of biologically active, readily synthesized fragments of the leptin molecule has drawn considerable attention, as they may provide a powerful tool for detailed characterization of the biological actions of leptin in different experimental settings. Recently, a fragment of mouse leptin protein comprising amino acids 116-130, termed leptin(116-130) amide, was shown to mimic the effects of the native molecule in terms of body weight gain and food intake, and to elicit LH and prolactin (PRL) secretion in vivo. As a continuation of our previous experimental work, the present study reports on the effects of leptin(116-130) amide on basal and stimulated testosterone secretion by adult rat testis in vitro. In addition, a comparison of the effects of human recombinant leptin and leptin(116-130) amide at the pituitary level on the patterns of LH, FSH, PRL and GH secretion is presented. As reported previously by our group, human recombinant leptin $\left(10^{-9}\right.$ $10^{-7} \mathrm{M}$ ) significantly inhibited both basal and human chorionic gonadotrophin (hCG)-stimulated testosterone secretion in vitro. Similarly, incubation of testicular tissue in the presence of increasing concentrations of leptin $(116-130)$ amide $\left(10^{-9}-10^{-5} \mathrm{M}\right)$ resulted in a dose-dependent inhibition of basal and hCG-stimulated testosterone secretion; a reduction that was significant from a dose of $10^{-7} \mathrm{M}$ upwards. In addition, leptin(116-130) amide, at all doses tested $\left(10^{-9}-10^{-5} \mathrm{M}\right)$, significantly decreased LH and FSH secretion by incubated hemi-pituitaries from adult male rats. In contrast, in the same experimental protocol, recombinant leptin $\left(10^{-9}-10^{-7} \mathrm{M}\right)$ was ineffective in modulating LH and FSH release. Finally, neither recombinant leptin nor leptin(116-130) amide were able to change basal PRL and GH secretion in vitro. Our results confirm the ability of leptin, acting at the testicular level, to inhibit testosterone secretion, and map the effect to a domain of the leptin molecule that lies between amino acid residues 116 and 130. In addition, we provide evidence for a direct inhibitory action of leptin(116-130) amide on pituitary LH and FSH secretion, a phenomenon not observed for the native leptin molecule, in the adult male rat.
\end{abstract}

European Journal of Endocrinology 142 406-410

\section{Introduction}

Leptin, the product of the $o b$ gene, is an adipocytesecreted plasma hormone involved in the control of food intake and energy expenditure that plays a key role in body weight homeostasis $(1,2)$. Moreover, leptin has recently emerged as a pivotal signal in the regulation of fertility and neuroendocrine function. The absence of biological actions of leptin, due to mutations in the $o b$ gene ( $o b / o b$ mice), leads to infertility whereas leptin administration advances the onset of puberty, maintains reproductive cyclicity despite acute fasting, and prevents sterility in $o b / o b$ mice $(2,3)$. In addition, evidence for a stimulatory role of leptin in the control of growth hormone $(\mathrm{GH})$ and luteinizing hormone $(\mathrm{LH})$ secretion has been presented $(4,5)$. The mechanisms behind the wide range of biological actions of leptin are far from being completely elucidated, but compelling evidence points to the hypothalamus as the primary target for most of the metabolic and endocrine actions of leptin(6). However, based on the characterization of leptin receptor distribution and leptin effects on in vitro 
systems, additional primary sites for leptin action have been suggested, including the pituitary, testis and ovary $(7-11)$.

Different experimental approaches have been used to delineate the effects and mechanisms of the action of leptin. Among them, testing of the biological action of several synthetic peptides generated to replicate restricted areas of the leptin protein has helped to identify active domains of the molecule in terms of regulation of body weight and food intake $(12,13)$. Interestingly, it was shown recently that a fragment of the murine leptin protein comprising amino acids 116-130 (termed leptin(116-130) amide) displayed actions similar to those of the native molecule in terms of food intake and body weight in female $o b / o b$ mice (13). In addition, we demonstrated recently that this synthetic peptide was able to elicit $\mathrm{LH}$ and prolactin (PRL) secretion in fasted adult male rats (14). As a continuation of our previous work $(10,14)$, the present experiments were undertaken to characterize the effects of leptin(116-130) amide on anterior pituitary secretion and testicular testosterone production in vitro. Comparative analyses revealed that the biological actions of leptin(116-130) amide on the pituitarytesticular axis involve effects both similar to and distinct from those of the native leptin molecule in the adult rat.

\section{Materials and methods}

\section{Animals and drugs}

Adult (75-day-old) Wistar male rats bred in the vivarium of our Institution were used. The animals were caged under constant conditions of light $(14 \mathrm{~h}$ of light; lights on at $0700 \mathrm{~h})$ and temperature $\left(22^{\circ} \mathrm{C}\right)$, with free access to pelleted food (Pacsa Sanders, Seville, Spain) and tap water. Experimental procedures were approved by the Córdoba University Ethical Committee for animal experimentation and were conducted in accordance with the European Union normative for care and use of experimental animals.

Human recombinant leptin was kindly donated by Eli Lilly (Indianapolis, IN, USA). Mouse leptin(116-130) amide was purchased from Bachem AG (Bubendorf, Switzerland). LH-releasing hormone (LHRH) was obtained from Sigma (Sigma Chemical Co., St Louis, MO, USA).

\section{Tissue incubations}

For the analysis of the direct effects of recombinant leptin and leptin(116-130) amide on anterior pituitary secretion in vitro, incubation of pituitary tissue from adult males was carried out as described elsewhere (10). Briefly, upon decapitation of experimental animals, anterior pituitaries were immediately removed, dissected free of the posterior pituitary lobe, and halved. Hemi-pituitaries were preincubated for $1 \mathrm{~h}$ in
$1 \mathrm{ml}$ Dulbecco's modified Eagle's medium (DMEM)Ham's F12 medium (1:1; Life Technologies, Grand Island, NY, USA) supplemented with $0.1 \mathrm{~g} / \mathrm{l}$ gentamicin (Biological Industries, Bet-Haemek, Israel) in a Dubnoff shaker $(60$ cycles $/ \mathrm{min})$ at $37{ }^{\circ} \mathrm{C}$ under an atmosphere of $5 \% \mathrm{CO}_{2}-95 \% \mathrm{O}_{2}$. After preincubation, the media were replaced either by fresh medium or medium containing increasing doses of leptin $\left(10^{-9}-10^{-7} \mathrm{M}\right)$ or leptin(116-130) amide $\left(10^{-9}-10^{-5} \mathrm{M}\right)$. As internal control for incubation conditions, a group of hemipituitaries was incubated in the presence of LHRH $\left(10^{-6} \mathrm{M}\right)$. After 60 and $120 \mathrm{~min}$, $50 \mu \mathrm{l}$ aliquots from the incubation media were taken for $\mathrm{LH}$, folliclestimulating hormone (FSH), PRL and GH measurements, as described below. Hormonal levels were expressed as normalized values per $10 \mathrm{mg}$ incubated tissue.

Assessment of in vitro effects of leptin(116-130) amide on testosterone secretion was carried out using static incubation of testicular tissue from adult rats. For this purpose, testes were removed immediately upon decapitation of experimental animals, decapsulated, and cut into pieces of approximately equal size (mean weight/piece: $385+7 \mathrm{mg} /$ piece from adult testes, 4 slices/testis). Testicular slices (2 slices/well) were incubated in $2 \mathrm{ml}$ gentamicin-supplemented DMEM-F12 medium in a Dubnoff shaker $(60$ cycles $/ \mathrm{min})$ at $32{ }^{\circ} \mathrm{C}$ under an atmosphere of $5 \% \quad \mathrm{CO}_{2}-95 \% \quad \mathrm{O}_{2}$. After preincubation for $1 \mathrm{~h}$, the media were replaced either by fresh medium or medium containing increasing doses of leptin(116-130) amide $\left(10^{-9}-10^{-5} \mathrm{M}\right)$. In addition, to test the ability of this leptin-related peptide to modulate stimulated testosterone secretion, groups of testicular samples were challenged with different doses of leptin(116-130) amide $\left(10^{-9}-10^{-5} \mathrm{M}\right)$ plus hCG (10 IU) or hCG alone. For comparative analysis, a similar experimental procedure was carried using recombinant leptin $\left(10^{-9}-10^{-7} \mathrm{M}\right)$, in the presence or absence of hCG (10 IU). After $90 \mathrm{~min}, 100 \mu \mathrm{l}$ aliquots from the incubation media were taken for testosterone measurement, as described below. The levels of testosterone in the media were expressed as normalized values per $1 \mathrm{~g}$ incubated tissue.

\section{Hormone measurements and statistics}

Testosterone was measured from diethyl ether extracts of tissue incubation media by RIA using ${ }^{3} \mathrm{H}$-labelled testosterone as tracer. LH, FSH, PRL and $\mathrm{GH}$ levels were assayed in incubation media by specific RIAs, using kits supplied by NIDDK (Bethesda, MD, USA). The results are expressed using reference preparation (RP) LH-RP-3, FSH-RP-2, PRL-RP-3 and GH-RP-2 as standards.

Experiments were carried out in duplicate. Data are expressed as means \pm s.E.M. $(n=8-12$ samples/group). Results were analyzed for statistically significant differences using a one-way ANOVA, followed by Tukey's test. $P<0.05$ was considered significant. 


\section{Results}

Comparison of the effects of human recombinant leptin $\left(10^{-9}-10^{-7} \mathrm{M}\right)$ and leptin(116-130) amide $\left(10^{-9}-\right.$ $\left.10^{-5} \mathrm{M}\right)$ on basal pituitary function of adult male rats was carried out. Assuming that the biopotency of the synthetic peptide is lower than that of the native molecule (13), a wider range of doses were tested for leptin(116-130) amide. Recombinant leptin, at all doses evaluated, failed to change basal release of LH, FSH, PRL and GH by incubated pituitary tissue. However, as a positive control, under similar incubation conditions $10^{-6} \mathrm{M}$ LHRH elicited a significant 2.5- and 3-fold increase in LH and FSH secretion respectively (data not shown). In the same experimental set-up, leptin(116-130) amide was unable to alter basal PRL and GH release. However, at all doses tested, leptin(116-130) amide induced a significant inhibition of LH and FSH secretion by incubated hemi-pituitaries from adult male rats (Fig. 1).

In addition, assessment of the effects of leptin(116130) amide on basal and hCG-stimulated testosterone secretion in vitro was carried out after $90 \mathrm{~min}$ static incubation of testicular tissue, as this incubation time has previously been proven effective for demonstrating the direct inhibitory action of recombinant leptin on testosterone release (10). Moreover, in order to compare the potency of the leptin fragment and the native leptin molecule in suppressing testosterone secretion in vitro, evaluation of the effects of recombinant leptin under similar experimental conditions was included. In keeping with our previous reference (10), doses of $10^{-9}-10^{-7} \mathrm{M}$ leptin significantly decreased basal and hCG-induced testosterone secretion in vitro. As was the case for the native molecule, incubation of testicular samples from adult rats in the presence of increasing concentrations of leptin(116-130) amide $\left(10^{-9}-\right.$ $\left.10^{-5} \mathrm{M}\right)$ resulted in a significant inhibition of basal and hCG-stimulated testosterone secretion; an inhibition that appeared dose dependent: $10^{-9} \mathrm{M}$ leptin(116130) was ineffective whereas a significant reduction in basal and stimulated testosterone release was observed for $10^{-7}-10^{-5} \mathrm{M}$ doses (Table 1).

\section{Discussion}

In recent years, characterization of the biological effects and mechanisms of action of leptin has drawn considerable attention. Among the different experimental approaches, synthetic peptide technology has been used $(12,13)$. Testing of the biological action of several synthetic peptides generated to replicate restricted areas of the leptin protein has helped to identify those domains of the molecule that are responsible for its metabolic and endocrine effects $(12-14)$. Moreover, the availability of biologically active, small, readily synthesized fragments of leptin could ease the characterization of the effects of the native molecule both in
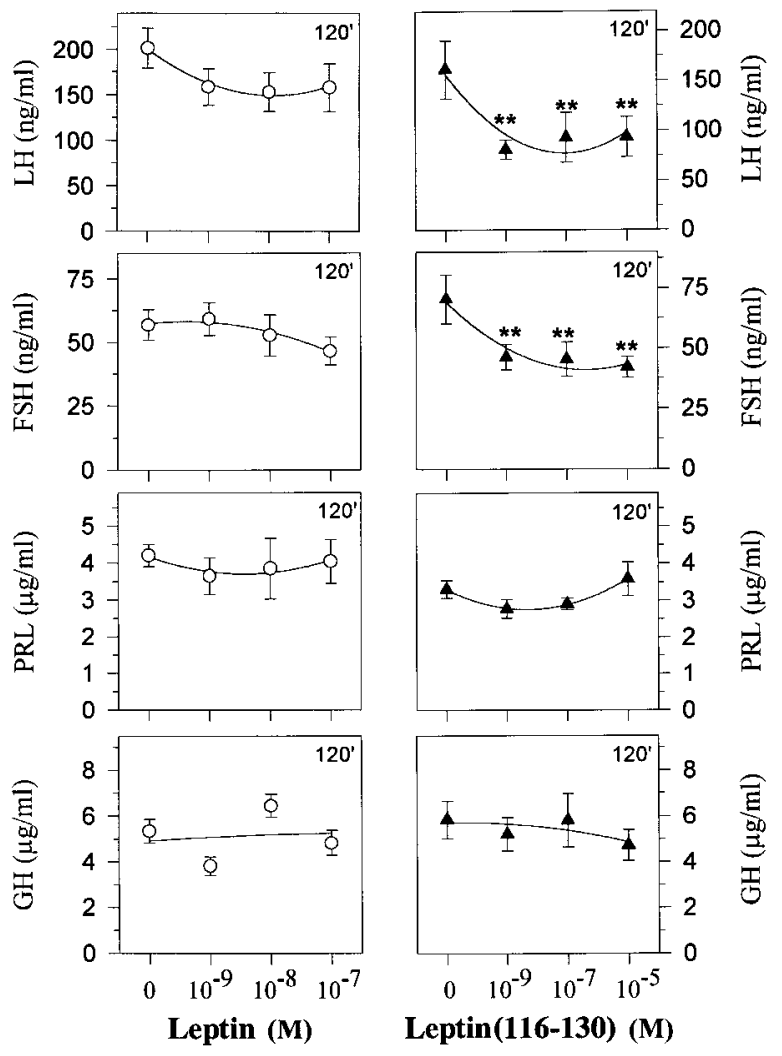

Figure 1 Effects of recombinant leptin(left panels) and the leptin-related synthetic peptide, leptin(116-130) amide, (right panels) on in vitro $\mathrm{LH}, \mathrm{FSH}, \mathrm{PRL}$ and $\mathrm{GH}$ secretion in adult male rats. Hemi-pituitaries were incubated in the presence of increasing concentrations of human recombinant leptin $\left(10^{-9}-10^{-7} \mathrm{M}\right)$ or leptin $(116-130)$ amide $\left(10^{-9}-10^{-5} \mathrm{M}\right)$. As the pattern of hormone release was similar after 60 and 120 min incubation, only data from the latter incubation are presented. Values are given as means \pm S.E.M. ( $n=8-10$ samples/group). ${ }^{* *} P<0.01$ vs control samples incubated in the presence of DMEM alone (ANOVA followed by Tukey's test).

physiological and pathological conditions and pave the way for development of therapies based on the use of potent leptin analogs. The ability of a fragment of the mouse leptin molecule, comprising amino acids 116-130, to mimic the actions of the native protein in terms of food intake and body weight gain, and to elicit LH and PRL secretion in vivo $(13,14)$, prompted us to evaluate its potential effects on anterior pituitary secretion and testicular testosterone production in vitro. In this sense, leptin receptors have been localized in these areas (7) and evidence has been presented for a direct regulatory role of leptin on testicular and pituitary function $(8-10)$.

Incubation of testicular tissue in the presence of increasing concentrations of leptin(116-130) amide resulted in a dose-dependent inhibition of basal and hCG-stimulated testosterone secretion. These results confirm our previous data on the ability of leptin to inhibit testosterone secretion in vitro (10). Moreover, 
Table 1 Effects of the leptin-related synthetic peptide, leptin(116-130) amide, on in vitro basal (-hCG) and hCG-stimulated $(+\mathrm{hCG})$ testosterone $(\mathrm{T})$ secretion in adult rats. To evaluate regulation of basal $\mathrm{T}$ secretion, slices of testicular tissue were incubated in the presence of increasing concentrations of leptin(116-130) amide $\left(10^{-9}-10^{-5} \mathrm{M}\right)$. In addition, to test the ability of leptin(116-130) amide to modulate stimulated T secretion, testicular samples were challenged with different doses of the peptide $\left(10^{-9}-10^{-5} \mathrm{M}\right)$ plus hCG (10 IU). For comparative analysis, results from incubations with recombinant leptin $\left(10^{-9}-10^{-7} \mathrm{M}\right)$, in the presence or absence of hCG $(10 \mathrm{IU})$, are presented. Testes incubated with medium alone served as respective controls. Values are given as means \pm S.E.M. ( $n=10-12$ samples/group).

\begin{tabular}{|c|c|c|c|c|}
\hline & \multicolumn{4}{|c|}{$\begin{array}{c}\text { T secretion } \\
(\mathrm{ng} / \mathrm{ml} \cdot \mathrm{g} \text { tissue })\end{array}$} \\
\hline & Control & $10^{-9} \mathrm{M}$ leptin(116-130) & $10^{-7} \mathrm{M}$ leptin(116-130) & $10^{-5} \mathrm{M}$ leptin(116-130) \\
\hline \multirow[t]{3}{*}{$\begin{array}{l}-\mathrm{hCG} \\
+\mathrm{hCG}\end{array}$} & $\begin{array}{r}8.36 \pm 1.02 \\
94.15 \pm 18.5\end{array}$ & $\begin{array}{l}7.72 \pm 1.16 \\
64.5 \pm 10.14\end{array}$ & $\begin{array}{l}4.51 \pm 0.69^{* *} \\
54.3 \pm 7.71^{* *}\end{array}$ & $\begin{array}{l}5.03 \pm 0.58^{\star *} \\
52.5 \pm 3.75^{\star *}\end{array}$ \\
\hline & \multicolumn{4}{|c|}{$\begin{array}{c}\text { T secretion } \\
(\mathrm{ng} / \mathrm{ml} \cdot \mathrm{g} \text { tissue })\end{array}$} \\
\hline & Control & $10^{-9} \mathrm{M}$ leptin & $10^{-8} \mathrm{M}$ leptin & $10^{-7} \mathrm{M}$ leptin \\
\hline $\begin{array}{l}-\mathrm{hCG} \\
+\mathrm{hCG}\end{array}$ & $\begin{array}{r}8.91 \pm 0.60 \\
101.2 \pm 13.7\end{array}$ & $\begin{array}{c}6.35 \pm 0.72^{\star *} \\
59.92 \pm 10.52^{*}\end{array}$ & $\begin{array}{r}6.61 \pm 0.46^{\star *} \\
55.25 \pm 6.36^{\star *}\end{array}$ & $\begin{array}{r}6.42 \pm 0.36^{\star *} \\
51.45 \pm 5.31^{\star *}\end{array}$ \\
\hline
\end{tabular}

${ }^{*} P<0.05 ;{ }^{* *} P<0.01$ vs values from corresponding control groups (ANOVA followed by Tukey's test).

the data presented herein allow the localization of this biological action to a domain of the leptin protein between amino acid residues 116-130. This domain appears as an important functional area of the molecule as it is involved in relevant metabolic and endocrine actions of leptin (13, 14 and present results). Interestingly, the effectiveness of leptin(116-130) in suppressing testosterone secretion in vitro was lower than that of the native molecule, as $10^{-9} \mathrm{M}$ doses were inhibitory only for the latter. The decreased biopotency of leptin(116-130) amide has also been reported for its effects on food intake (13), and likely depends on a lower affinity for the cognate receptor when compared with the intact protein.

Comparison of the effects of recombinant leptin and its active fragment on basal pituitary function in vitro revealed differences in the action of the two molecules. Leptin(116-130) amide induced a significant inhibition in LH and FSH secretion by incubated hemi-pituitaries whereas it was ineffective in terms of PRL and GH release (Fig. 1). The latter finding is in good agreement with previous reports on the lack of action of leptin on pituitary GH secretion in vitro $(4,15)$. In addition, these results are in line with the ability of leptin(116-130) amide to partially suppress basal LH secretion by pituitaries from ovariectomized, steroid-primed female rats in vitro (16), and are in keeping with our previous findings on the selective inhibition by recombinant leptin of basal LH and FSH release by pituitaries from adult fasted male rats (10). Present results, however, are in contrast to data obtained in normally fed animals using the complete leptin protein. On this point, both stimulatory effects $(8,9)$ and the absence of modulatory action (present results) of leptin on LH, FSH and PRL secretion by adult male rat pituitaries in vitro have been reported. The reasons behind such a discrepancy are unclear as similar experimental settings were used in these studies; yet differences in terms of rat strain and type and doses of leptin used were noted. Overall, however, a striking difference between the effects of recombinant leptin and leptin(116-130) amide on basal gonadotropin secretion can be outlined. The mechanism(s) underlying such a phenomenon may involve the presence of different leptin receptor isoforms. In this sense, several leptin receptor subtypes, with different biological roles, have been identified and the balance of their expression in rat brain appears to be regulated by hormonal and metabolic signals (17). In such a scenario, it is tempting to speculate that the net action of leptin on basal pituitary function derives from the activation of different subsets of receptors, and that the conflicting observations reported above may be due to differences in the binding affinities of the leptin molecule and its active fragment for different receptor isoforms. Interestingly, the identification of distinct patterns of response to recombinant leptin and leptin(116-130) amide in terms of basal LH and FSH secretion, reported herein, may help to understand the mechanism behind the controversial data gathered on the direct actions of leptin on anterior pituitary secretion under different experimental conditions (see above). In this sense, evaluation of the effects of leptin(116-130) amide on LH and FSH secretion by pituitaries from adult, fasted males may prove helpful to further extend our present data on the structure-function relationship of the leptin molecule in terms of regulation of basal gonadotropin secretion.

It is worthy of note that the effects of leptin(116130) amide in vitro were different from those observed 
in vivo, as the leptin fragment inhibited LH secretion and failed to alter PRL secretion by incubated hemipituitaries whereas it stimulated LH and PRL release when systemically administered to adult male rats (14). This observation, together with the lack of effect of recombinant leptin on pituitary secretion in vitro, reinforces the contention that the predominant actions of leptin in the control of anterior pituitary secretion are carried out mainly at the hypothalamic level $(4,7$, $8)$. In addition, our data point to a complex mode of action of leptin at multiple sites of the gonadotropic axis that likely involves both inhibitory and stimulatory effects.

In conclusion, our results further demonstrate the ability of leptin to inhibit testosterone secretion in vitro, and implicate a domain of the molecule between amino acid residues 116-130 in this action. In addition, based on comparative analyses, we propose that the biological action of leptin(116-130) amide on the pituitarytesticular axis involves effects both similar to and distinct from those of the native leptin molecule in the adult rat.

\section{Acknowledgements}

Materials for determination of LH, FSH, PRL and GH were supplied by NIDDK's National Hormone \& Pituitary Program and AF Parlow (Bethesda, MD, USA). Leptin was a generous gift from Eli Lilly (Indianapolis, IN, USA). The authors are indebted to Rocío Campón and Inmaculada Aguilar for their excellent technical assistance. This work was supported by grants from DGICYT (Ministerio de Educación y Cultura, Spain) and project 1FD97-0696-02 (FEDER)

\section{References}

1 Zhang Y, Proenca R, Maffei M, Barone M, Leopold L \& Friedman JM. Positional cloning of the mouse obese gene and its human homologue. Nature 1994372 425-432.

2 Rosenbaum M \& Leibel RL. Leptin: a molecule integrating somatic energy stores, energy expenditure and fertility. Trends in Endocrinology and Metabolism 1998 9 117-123.

3 Chehab FF, Mounzik K, Lu R \& Lim ME. Early onset of reproductive function in normal female mice treated with leptin. Science 1997 $27588-90$.
4 Carro E, Señaris R, Considine RV, Casanueva FF \& Diéguez C. Regulation of in vivo growth hormone secretion by leptin. Endocrinology 1997138 2203-2206.

5 Carro E, Pinilla L, Seoane LM, Considine RV, Aguilar E, Casanueva FF et al. Influence of the endogenous leptin tone on the estrous cycle and LH pulsatility in female rats. Neuroendocrinology 199766 375-377.

6 Schwartz MW, Seeley RJ, Campfield A, Burn P \& Baskin DG. Identification of targets of leptin action in rat hypothalamus. Journal of Clinical Investigation 199698 1101-1106.

7 Zamorano PL, Mahesh VB, De Sevilla LM, Chorich LP, Bhat GK \& Brann DW. Expression and localization of the leptin receptor in endocrine and neuroendocrine tissues of the rat. Neuroendocrinology 199765 223-228.

8 Yu WH, Kimura M, Walczewska A, Karanth S \& McCann SM. Role of leptin in hypothalamic-pituitary function. Proceedings of the National Academy of Sciences of the USA 199794 1023-1028.

$9 \mathrm{Yu}$ WH, Walczewska A, Karanth S \& McCann SM. Nitric oxide mediates leptin-induced luteinizing hormone-releasing hormone (LHRH) and LHRH and leptin-induced LH release from the pituitary gland. Endocrinology 1997138 5055-5058.

10 Tena-Sempere M, Pinilla L, González LC, Dieguez C, Casanueva FF \& Aguilar E. Leptin inhibits testosterone secretion from adult rat testis in vitro. Journal of Endocrinology 1999161 211-218.

11 Spicer LJ \& Francisco CC. The adipose obese gene product, leptin: evidence of a direct inhibitory role in ovarian function. Endocrinology $19971383374-3379$.

12 Samson WK, Murphy TC, Robison D, Vargas T, Tau E \& Chang J-W. A 35 amino acid fragment of leptin inhibits feeding in the rat. Endocrinology $19961375182-5185$.

13 Grasso P, Leinung MC, Ingher SP \& Lee DW. In vivo effects of leptin-related synthetic peptides on body weight and food intake in female ob/ob mice: localization of leptin activity to domains between amino acid residues 106-140. Endocrinology 1997138 1413-1418.

14 González LC, Pinilla L, Tena-Sempere M \& Aguilar E. Leptin ${ }_{116-}$ 130 stimulates prolactin and LH secretion in fasted adult male rats. Neuroendocrinology 199970 213-220.

15 Cocchi D, de Genaro Colonna V, Bagnasco M, Bonacci D \& Müller EE. Leptin regulates $\mathrm{GH}$ secretion in the rat by acting on GHRH and somatostatinergic functions. Journal of Endocrinology $199916295-99$.

16 González LC, Pinilla L, Tena-Sempere M, Diéguez C, Casanueva FF \& Aguilar E. Effect of acute immunoneutralization of endogenous leptin on prolactin and LH secretion during the afternoon of pro-estrus or in steroid-treated ovariectomized female rats. Journal of Reproduction and Fertility 2000 (in press).

17 Bennett PA, Lindell K, Karlsson C, Robinson ICAF, Carlsson LMS \& Carlsson B. Differential expression and regulation of leptin receptor isoforms in the rat brain: effects of fasting and oestrogen. Neuroendocrinology 199867 29-36.

Received 20 September 1999

Accepted 3 December 1999 